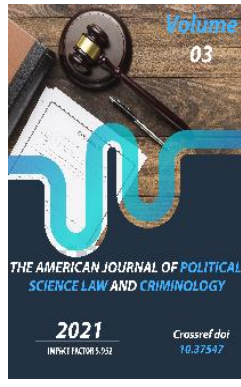

Journal Website: https://theamericanjou rnals.com/index.php/ta jpslc

Copyright: Original content from this work may be used under the terms of the creative commons attributes 4.0 licence.

\section{Special Features Of International Financial Centres And Its Establishment In Uzbekistan}

\author{
Ammar Younas \\ Researcher At University Of Chinese Academy Of Sciences Beijing, China \\ Turdialiev Mukhammad Ali Polatjon Ogli \\ PhD Candidate At Tashkent State University Of Law, Tashkent, Uzbekistan
}

\title{
ABSTRACT
}

The most important tasks in the field of economic development are attracting foreign investments into the economy of our country, creating favourable conditions for them, providing legal protection and further improving the investment climate. The article analyzes the basic concepts of the international financial centre and its brief history, the views of several scholars from different countries on international financial centres and their types. Prospects for the establishment of international financial centres in Uzbekistan were also studied. This was demonstrated as a result of the analysis of the legal, financial and other possibilities of establishing an international financial centre based on common law in Uzbekistan.

\section{KEYWORDS}

International financial centres, offshore zones, foreign trade and entrepreneurship, economic potential, legal regime.

\section{INTRODUCTION}

The current venture arrangement within the world and in our nation appears that in an advertising economy to profoundly change and fortify outside financial relations, to pull in more remote venture to the economy of our country, to contribute more within the economy of the republic, to contribute within the republic. In arrange to extend the viability of integration, it is vital to assist make strides the legitimate direction of speculations inside the free financial zones, their fascination, arrangement of benefits and inclinations.

Nowadays, the liberalization and modernization of the economy, subsequently 
accomplishing the generation of items that meet universal measures, requires the creation of favourable conditions for drawing in the remote venture, particularly coordinate venture. Of course, free financial zones play an imperative part within the execution of such pressing tasks. The developing drift of free financial zones within the world in later a long time, the assist advancement of remote exchange and speculation relations, the influx of remote coordinate speculation in these regions, as well as the improvement of new high-tech and competitive businesses. The increment within the level of these structures makes the requirement for the improvement of entrepreneurial action and its legitimate control. At the show, there are more than 4,300 interesting free financial zones around the world.

\section{MATERIALS AND METHODS}

Worldwide money related centres are an unused frame of free financial zones. Universal monetary centres can be called an unused era of free financial zones. Worldwide money related centres are one of the prospects for improvement in today's world financial community. Universal money related centres are a put where banks and specialized money related education are locked in in worldwide cash operations, credit and bank, securities and gold operations. There are universal budgetary centres in London, Modern York, Zurich, Frankfurt is Primary, Luxembourg, Singapore and other nations around the world. In specific, within the neighbouring Republic of Kazakhstan in 2018, the Worldwide Money related Center "Astana" started its work. This, in turn, proves the vital part of international monetary centres within the country's economy.
I believe that Uzbekistan should apply English law in business as well. Before establishing an international arbitration and international financial centre in Kazakhstan, we studied the experience of Qatar and the application of English law in them. I think that this system has shown effective results in our country as well. Thus, Kazakhstan and Uzbekistan have common goals: to attract investors, to develop business internationally. That is why Uzbekistan will benefit from choosing this path.

According to the analysis, in the experience of developed countries (USA, China, South Korea, the United Arab Emirates, etc.), the introduction of innovations in free economic zones is growing. From this point of view, to create more favourable conditions for participants in free economic zones, further simplification of administrative procedures and permitting rules, improvement of business regulation, an increase of investment attractiveness and protection of investors' rights and legitimacy mechanisms.

During the short period passed by President Sh.M.Mirziyoev, the decrees and resolutions issued for the rapid development of investment activities and the establishment of new free economic zones, in particular, the right to apply tax rates and other mandatory payments in force on the date of transfer" [1].

It is specified in the Action Strategy for the five priority areas of development of the Republic of Uzbekistan for 2017-2021, approved by the Decree of the President of the Republic of Uzbekistan dated February 7, 2017 PD-4947 “... Increase the efficiency of free economic zones, technoparks and small industrial zones operating in the country, the creation of new 
ones..." [2]. It is necessary to create more opportunities for investment in the free economic zones operating in the country, to pay special attention to the promotion of foreign trade and entrepreneurship in these areas, and to ensure the proper position of our country in the world market.

Z/Yen Group Limited, a British financial company, was the first to try to bridge this gap between financial centres and international financial centres. It is worthwhile to briefly mention Z /Yen Group Limited. Founded in 1994 in London, Z/Yen Group Limited is a company with high results and many years of experience in providing risk management advice to investors and entrepreneurs. At the same time, this financial company is engaged in strategic planning, business education, financial evaluation, liquidation and localization of companies, as well as research in various sectors of the economy.

Bank of America, Barclays Capital, HSBC, McKinsey \& Co, PricewaterhouseCoopers, UBS, London Stock Exchange, Russian Stock Exchange-MICEX and other financial institutions, BP Oil International, British Telecom, Cisco, Hitachi Europe Limited, Shell International, Siemens companies, non-profit organizations such as The British Council, the Global Policy Institute, and government agencies use the services of Z/Yen Group Limited.

One of Z/Yen Group Limited's extensive activities is to compile an annual international ranking of international financial centres and intellectual property.
Z/Yen Group Limited lists the following types of international financial centres by the scope of activity.

- The Global Financial Center is a centre that reflects the financial institutions of the world, interconnecting national, regional and global representatives of the financial sector.

- International financial centres are the centres that act as coordinators in the implementation of international agreements and open transactions between financial sectors located in different parts of the world.

- Specialized financial centres are one of the most common types of financial centres, coordinating the world's leading banks, insurance and financial institutions in a particular area of the financial market. These types of financial centres specialize in one type of financial market.

- Financial centres at the national level - the centre for trade, finance and banking operations of the host country. These types of financial centres are also characterized by the ability of the host country to conduct international financial transactions.

- Local financial centres are smaller than other financial centres in terms of operations and financial transactions, and these types of financial centres are radically different from other centres in that they conduct local financial transactions within a country.

It should be noted that the financial centre of the same category can also perform the functions of other types of financial centres. Examples are the financial centres of London and New York. 
In some cases, we can also categorize financial centres according to the language used there. Currently, there is a category of "English language centres" in this category. This category includes financial centres located in Australia, New Zealand, South Africa and London. The financial centres of Frankfurt or Tokyo are the opposite of this category, that is, we can fall into the category of centres that operate in their language.

It should be noted that among the leading financial centres there are also financial centres included in the list of offshore zones. These include financial centres such as Hong Kong, Singapore, the Isles of Maine, Jersey, Guernsey. At the same time, they are also called offshore financial centres.

There are currently several types of international financial centres. The first classification of international financial centres into categories was made in the 1980 s by the American economist John Friedman [3]. As a result of his research, he hierarchically classified the international financial centres as follows:

- Top financial centres - London, New York, Tokyo;

- Multinational financial centres - Miami, Los Angeles, Frankfurt, Amsterdam, Singapore;

- Important national financial centres - Paris, Zurich, Madrid, Mexico, Sao Paulo, Seoul, Sydney.

In 1999, the Globalization and World Cities Study Group and a joint working group set up by the University of Luffbo in the United Kingdom to study globalization and international centres were divided into the following groups. In allocating them to these groups, financial centres were assessed on a 12point scale based on their level of development.

1. Alpha category - London, New York, Paris, Tokyo - 12 points, Chicago, Frankfurt, Hong Kong, Los Angeles, Milan, Singapore - 10 points;

2. Beta category - San Francisco, Sydney, Toronto, Zurich - 9 points, Brussels, Madrid, Mexico City, Sao Paulo - 8 points, Moscow, Seoul - 7 points;

3. Gamma category - Amsterdam, Boston, Caracas, Dallas, Düsseldorf, Geneva, Houston, Jakarta, Johannesburg, Melbourne, Osaka, Prague, Santiago, Taipei, Washington - 6 points, Bangkok, Beijing, Bicolcol, Beijing, Montreal, Montreal, Atlanta, Barcelona, Berlin, Buenos Aires, Budapest, Copenhagen, Hamburg, Istanbul, Kuala Lumpur, Manila, Miami, Minneapolis, Munich, Shanghai - 4 points.

\section{RESULTS AND CONCLUSION}

Based on the above, we would like to suggest that it is necessary to establish the International Financial Center and launch a separate legal regime in the Tashkent city international business centre with all the essential facilities and infrastructure for global financial centres.

First, it is necessary to develop the legal framework and corporate governance system of the Tashkent International Financial Center. The transformation of the Tashkent city international business centre into a global financial centre will require about $\$ 60-70$ 
million. This amount is calculated based on international experience.

There are several strategic goals for the creation of the Tashkent International Financial Center, which should be designated as the strategic directions of the Tashkent International Financial Center:

- Development of the capital market;

- Development of asset management;

- The attraction of Islamic finance;

- Improving the quality of property management;

- Development of financial technologies;

Based on the experience of the international financial centres of Astana and Dubai, the gradual creation of the Tashkent International Financial Center in the Tashkent International Business Center and the introduction of English law in it will take about five years. It will take about ten years for this international financial centre to become financially independent.

Based on the international experience of creating those mentioned above global financial centres, we can say that Uzbekistan's current economic potential is sufficient to meet these requirements. In conclusion, we can positively assess the current prospects for creating the International Financial Center of Uzbekistan and the present British legislation. property and improving the quality of the business environment", 2016.

2. №4917 decree of President of the Republic of Uzbekistan on "National Action Strategy for Five Priority Development Areas in 2017-2021", 2017.

3. Drobyshevskiy S.M., Khudko E.V., Velikova E.E. (2010). Perspectives on the creation of an international financial centre in the Russian Federation. Moscow. Gaydara Institute. $28 \mathrm{p}$.

4. Zayniddinov, R. (2020). Socioeconomic development with foreign trade (trio of emerging markets, transition economy and investment attractiveness). Архив научных исследований, (22).

\section{REFERENCES}

1. №4848 decree of President of the Republic of Uzbekistan on "On additional measures to ensure the rapid development of the entrepreneurial activity, comprehensive protection of private 